\title{
Wage differentials between the public and private sectors in Chile: Evidence from longitudinal data
}

\author{
Lucas Navarro and Javiera Selman
}

ABSTRACT

Despite its importance, the literature on wage differentials between public- and privatesectors employees in Latin America is sparse. This article analyses the wage gap between the two sectors in Chile, based on monthly longitudinal data obtained from the Social Protection Survey (EPS) for the period 2002-2009. The study takes advantage of the panel structure of the data to control for time-invariant observable and unobservable factors that determine the self-selection of workers between sectors and wages. The results show that the wage differential between workers in the public and private sectors disappears when these factors are controlled for. models, Chile 


\section{I}

\section{Introduction}

A large proportion of the labour force throughout the world is employed in the public sector. According to data from the Organization for Economic Cooperation and Development (OECD, 2011), the public sector provides $30 \%$ of all jobs in Norway and Denmark, $22 \%$ in France and $16 \%$ in the United States. Although public employment accounts for roughly $15 \%$ of total employment across Latin America, and 10\% in Chile specifically (Mizala, Romaguera and Gallegos, 2011), there has been very little comparative analysis of employment and wages in the two sectors in the region. The present study contributes to the literature by analysing the wage gap and mobility between the public and private sectors among wage-earners in Chile, using panel data from the Social Protection Survey (EPS) for the period 2002-2009.

Employment in the public and private sectors has specific features that may affect pay in each sector: (i) some productive activities are undertaken typically either by the public or by the private sector; (ii) publicsector hiring often obeys different rules than those of the private sector (political decisions for example); (iii) the public sector is regulated by specific legislation on employment conditions; and, in addition, compliance with general labour legislation is much stricter in the public sector than in the private sector in many countries. There is also evidence that public-sector workers are more risk-averse and display a greater preference for public services and non-profit institutions (Gregory and Borland, 1999).

The literature on wage differences between publicand private-sector workers comes mainly from developed countries. In general, studies provide evidence of a premium for working in the public sector, which is higher among women but declines over the wage distribution,

$\square$ Research financed through the Research Initiation Project No. 11100131 of the National Fund for Technological and Scientific Development (FONDECYT). The authors thank Claudio Agostini, Ramiro de Elejalde, Marcela Perticará and Rodolfo Stucchi for their useful comments. and can even become negative. ${ }^{1}$ The evidence also shows that the public-sector wage distribution is less dispersed than its private sector counterpart, even when observable characteristics are controlled for (Bender and Elliott, 1999).

An important methodological issue when analysing inter-sectoral wage differences is that workers have variable unobservable characteristics (innate abilities, motivation, risk aversion and others). These affect their wage and the decision to work in the private or public sector, thereby biasing the results. Using data from the United States, Krueger (1988) finds that, when using longitudinal data and correcting for selection bias, the unexplained wage gap between the sectors is substantially smaller than that obtained from ordinary least squares (OLS) estimations with cross-section data. More recent studies, such as Lee (2004) for the United States, have obtained similar results.

Among the most recent studies, Bargain and Melly (2008) use longitudinal data for France and estimate the average wage gap with a fixed-effects model and quantile regressions with fixed effects (Koenker, 2004). The results show that the average differential is not different from zero, there are no differences between men and women, and the gap does not vary over the wage distribution. The authors attributed the gap observed in earlier studies, and the smaller dispersion of wages in the public sector, exclusively to individual selection. ${ }^{2}$ In another study, Siminski (2013) analyses whether there are differences in the return to skills between sectors, using a model of quasi-differences with the generalized

\footnotetext{
1 Lucifora and Meurs (2006), using quantile regressions, detect a premium for working in the public sector in France, Italy and the United Kingdom, which varies between $8 \%$ and $15 \%$ in the first deciles of the wage distribution, and then decreases until it vanishes in the ninth decile. Women always obtain a positive premium and men obtain higher returns from working in the private sector in most of the distribution. Melly (2005), using data from Germany and a quantile regression decomposition used by Machado and Mata (2005), finds that the public sector premium becomes negative in the 25 th percentile for men and in the 75th percentile for women.

2 These results are in line with those found by Disney and Gosling (2008) and by Postel-Vinay and Turon (2007) for Great Britain and Northern Ireland, respectively.
} 
method of moments (GMM), and finds that there are no premia (penalties) across the distribution, but that the higher (lower) wages observed in the public sector are explained by individual selection. The author points out that if the public sector attracts the best workers among the least skilled and the worst among the higher skilled, the differential will reflect productivity and not state inefficiency. ${ }^{3}$

In the case of Latin America, there is little evidence of research analysing the wage public-private sector wage gap. The study by Mizala, Romaguera and Gallegos (2011) uses cross-section data for 11 countries in the region over the period 1992-2007 to estimate the mean and distribution of the differential between the two sectors (for both wage-earners and self-employed workers). The study finds that, after controlling for observable characteristics using a matching procedure, the gap shrinks although it remains positive in all countries. The data for Chile reported in Mizala, Romaguera and Gallegos (2011) show that the wage gap widened from 3\% in 1996 to $13 \%$ in 2006, which is less than estimated for other countries in the region. This positive differential is mainly explained by wage differences between public-sector workers and self-employed workers in the private sector; because, when wage-earners in the private sector are compared with their public-sector counterparts, the unexplained

3 Awarding a premium or a penalty not related to the worker's skill or productivity generates an inefficient allocation of resources. gap disappears. Analysing the public-private wage gap across the distribution, the authors detected a premium of about $10 \%$ for working in the public sector in the first deciles of the distribution; but this becomes negative in the 75th percentile and reaches a maximum penalty of $34 \%$ in the 95 th percentile.

The present study takes advantage of the panel structure of the data to estimate the average wage gap in Chile between wage-earners in the public and private sectors, and to characterize mobility between sectors. Longitudinal data make it possible to control for time-invariant observable and unobservable factors that affect wages and the workers' selection between sectors. It is also possible to consider the effect of employment-history variables on wages, which are normally omitted in cross-section surveys. This study estimates the unexplained wage gap between workers in the public and private sectors using a fixed effects model combined with matching techniques to control for selection. The results show that while public-sector workers have a higher observed average wage than their private-sector counterparts, the gap disappears when observable and unobservable factors that are constant through time are controlled for.

This article is structured as follows: section II presents the data used and makes a descriptive analysis of the wage gap and mobility between the public and private sectors. Section III describes the methodology and econometric results; and section IV sets forth the conclusions.

\section{II}

\section{Data and descriptive statistics}

This study uses data from the Social Protection Survey (EPS) administered by the Office of the Under-Secretary for Social Protection of the Ministry of Employment and Social Protection of Chile. The EPS is the country's most important longitudinal survey, given its size and sample design representative of the population over 18 years of age, and the large amount of information it obtains from its interviewees. It has been applied in 2002, 2004, 2006, 2009 and 2012, although data from the most recent wave is not yet available.

For the purposes of this study, based on information from the employment histories contained in the EPS for
2004, 2006 and 2009, ${ }^{4}$ a monthly panel was constructed between January 2002 and December 2009 to analyse the wage differential between wage-earners in the public and private sectors and the mobility of workers between these sectors. Initially, the monthly panel contained information on 12,225 individuals. Nonetheless, to perform

\footnotetext{
4 The 2002 survey inquired into employment history between 1980 and 2002, for an exclusive sample of pension-system affiliates. Accordingly, only that database was used to construct some of the variables of employment history since 1980, which for the rest of the sample were obtained from the 2004 survey.
} 
the analysis, persons who were unemployed, inactive, or both $(2,739)$, throughout the period were eliminated, along with another 180 that presented inconsistencies in their data. Accordingly, the final database is an unbalanced panel containing information on 9,306 individuals over a period of 96 months.

In this article, public-sector workers are defined as individuals who work as white-collar employees or manual workers in that sector, excluding members of the armed forces. Although it would be interesting to distinguish between individuals working in public enterprises and those working in central or municipal government, the EPS data do not allow for this distinction.

Table 1 shows the sector composition of employed labour, distinguishing between wage earners and self-employed workers in the private sector. In general, the data show a relative increase in the size of the public sector relative from $10 \%$ to $12 \%$ of all employed workers, at the expense of the wage-earning private sector. ${ }^{5}$

As noted in the introduction, one of the advantages of using longitudinal data is that it becomes possible to detect the dynamics of individual employment histories. Table 2 shows the status transition matrix between 2002 and 2009, considering five alternative labour market statuses which may apply to a worker at a given moment in time: employed in the public sector, employed as a

5 With the aim of validating the data in table 1, appendix table A.1 shows the distribution between sectors based on the National Socioeconomic Survey (CASEN) of the Ministry of Social Development, for various years within the period analysed here. The data show a sectoral employment structure that is similar to that of the EPS sample used in this study. The only difference is that there tends to be a lower weight for waged employment in the private sector and a higher weight for self-employment in the private sector in the EPS compared to the CASEN survey over the last few years.

TABLE 1

Distribution of the employed labour force by sectors

(Percentages)

\begin{tabular}{lccccc}
\hline & & Public & Private wage-earning & Private self-employed & Total \\
\cline { 3 - 4 } Year & No. of observations & & (Percentages) & \\
\hline 2002 & 6755 & 10.0 & 65.4 & 24.6 & 100 \\
2003 & 6834 & 10.1 & 64.8 & 25.1 & 100 \\
2004 & 6849 & 10.1 & 64.6 & 25.3 & 100 \\
2005 & 6948 & 12.1 & 61.8 & 26.1 & 100 \\
2006 & 6985 & 12.1 & 61.3 & 26.6 & 100 \\
2007 & 6984 & 12.0 & 63.3 & 24.7 & 100 \\
2008 & 7029 & 12.0 & 63.0 & 25.0 & 100 \\
2009 & 6781 & 12.2 & 62.0 & 25.8 & 100 \\
\hline
\end{tabular}

Source: prepared by the authors on the basis of data from the Social Protection Survey (EPS).

TABLE 2

Labour mobility: transition matrix in relation to 2002 and 2009

(Percentages)

\begin{tabular}{lcccccc}
\hline & \multicolumn{3}{c}{2009} & & \\
\cline { 2 - 7 } 2002 & Public & $\begin{array}{c}\text { Private wage- } \\
\text { earning }\end{array}$ & Self-employed & Unemployed & Inactive & Total \\
\hline Public & 64.5 & 18.1 & 3.9 & 3.9 & 9.6 & 100 \\
Private wage-earning & 4.5 & 63.7 & 10.6 & 9.4 & 11.8 & 100 \\
Self-employed & 2.5 & 18.2 & 52.6 & 7.7 & 19.0 & 100 \\
Unemployed & 5.6 & 41.7 & 15.6 & 16.4 & 20.7 & 100 \\
Inactive & 6.5 & 36.1 & 15.7 & 13.7 & 28.0 & 100 \\
\hline
\end{tabular}

Source: prepared by the authors on the basis of data from the Social Protection Survey (EPS). 
wage-earner in the private sector, self-employed in the private sector, unemployed, or inactive.

From a long-term perspective, considering only the years at the start and end of the period under analysis, the data show that roughly two thirds of individuals employed in the private sector, and a similar fraction of public-sector employees, remained in that situation. The most frequent movement is within the private sector (between private-sector wage-earning employment and self-employment); nonetheless, the transition from wageearning private-sector employment to employment in the public sector is not negligible, given the larger number of employees in the wage-earning private sector. Moreover, of those who were initially in the public sector, $22 \%$ were private-sector employees in $2009,18 \%$ as wage-earners and $4 \%$ as self-employed. These figures suggest that there is a turnover of jobs between the public and private sectors; and there is also significantly lower probability of becoming long-term unemployed or inactive from the public than from the private sector.

Table 3 shows the extent to which the individuals in the sample changed their employment status each year. The data show a degree of time volatility in the status-transition patterns, which may be reflecting the country's business and political cycle. Between the periods 2004-2005 and 2006-2007 there is greater mobility both between sectors and into unemployment or inactivity. In the case of public-sector employees, who mostly moved into wage-earning jobs in the private-sector, this coincides with the implementation of the Public Senior Management System and the New Treatment Law in $2004,{ }^{6}$ and with the change of government in 2006.

The hourly wage per month, which is the main variable of interest in this study, was calculated from information compiled in the survey on weekly hours worked, and monthly income from work. ${ }^{7}$ Table 4 shows the trend of the average real hourly wage in the public and wage-earning private sector each year, expressed in terms of 2009 prices deflated by the consumer price index (IPC) calculated by the National Institute of Statistics (INE). The data show that the wage gap (public wage minus private wage) stayed in a range of $31 \%$ to $41 \%$,

6 The New Treatment Law established a group performance evaluation system that encourages employees to meet pre-defined targets. Prior to this law, evaluation was based on individual performance. The Public Senior Management System requires senior public positions to be appointed through public and transparent competitive processes.

7 The calculation defines a month as consisting of 4.2 weeks.
TABLE 3

Annual transition matrices, 2002-2009

(Percentages)

\begin{tabular}{lrrrrr}
\hline & \multicolumn{5}{c}{2003} \\
\cline { 2 - 6 } 2002 & Public & Private & Self-employed & Unemployed Inactive \\
\hline Public & 95.1 & 0.9 & 0.6 & 2.4 & 1.0 \\
Private & 0.4 & 91.2 & 1.1 & 4.7 & 2.6 \\
Self-employed & 0.0 & 1.1 & 96.7 & 1.1 & 1.1 \\
Unemployed & 1.2 & 16.8 & 3.8 & 76.9 & 1.3 \\
Inactive & 1.0 & 9.4 & 1.1 & 1.7 & 86.8 \\
\hline & \multicolumn{5}{c}{2004} \\
\hline
\end{tabular}

\begin{tabular}{|c|c|c|c|c|c|}
\hline 2003 & Public & Private & Self-employed & Unemployed & d Inactive \\
\hline Public & 96.0 & 0.6 & 0.2 & 1.7 & 1.5 \\
\hline Private & 0.2 & 92.1 & 0.9 & 4.3 & 2.6 \\
\hline Self-employed & 0 & 1.8 & 95.6 & 1.3 & 1.3 \\
\hline Unemployed & 1.4 & 18.8 & 3.5 & 74.9 & 1.3 \\
\hline Inactive & 0.6 & 8.2 & 1.0 & 1.3 & 88.9 \\
\hline
\end{tabular}

2005

\begin{tabular}{|c|c|c|c|c|c|}
\hline 2004 & Public & Private & f-emplo & hempl & nactiv \\
\hline Public & 76.2 & 17.5 & 2.3 & 1.7 & 2.3 \\
\hline Private & 5.0 & 72.9 & 9.9 & 7.2 & 5.0 \\
\hline Self-employed & 2.0 & 16.2 & 57.5 & 10.8 & 13.5 \\
\hline Unemployed & 2.9 & 36.3 & 14.2 & 27.3 & 19.3 \\
\hline Inactive & 2.1 & 20.9 & 14.7 & 19.8 & 42.5 \\
\hline
\end{tabular}

2006

\begin{tabular}{lrrrrr}
2005 & Public & \multicolumn{2}{c}{ Private } & Self-employed Unemployed Inactive \\
\cline { 2 - 4 } & 94.5 & 1.9 & 0.4 & 1.9 & 1.3 \\
Private & 0.4 & 91.8 & 0.9 & 4.4 & 2.5 \\
Self-employed & 0.1 & 1.8 & 95.9 & 1.4 & 0.8 \\
Unemployed & 1.7 & 18.5 & 4.2 & 74.6 & 1.0 \\
Inactive & 1.1 & 7.0 & 2.9 & 1.6 & 87.4 \\
\hline
\end{tabular}

2007

\begin{tabular}{|c|c|c|c|c|c|}
\hline 2006 & Public & Private & emplc & empl & nactive \\
\hline Public & 68.4 & 20.7 & 3.3 & 3.9 & 3.7 \\
\hline Private & 3.9 & 75.6 & 7.5 & 6.0 & 7.0 \\
\hline Self-employed & 1.8 & 21.6 & 55.9 & 5.7 & 15.0 \\
\hline Unemployed & 3.0 & 35.2 & 14.5 & 23.8 & 23.5 \\
\hline Inactive & 2.1 & 18.8 & 14.2 & 12.9 & 52.0 \\
\hline
\end{tabular}

2008

\begin{tabular}{|c|c|c|c|c|c|}
\hline 2007 & Public & Private & f-emplo & hemplc & nactive \\
\hline Public & 90.9 & 4.8 & 0.8 & 1.7 & 1.8 \\
\hline Private & 0.9 & 91.6 & 1.9 & 3.5 & 2.1 \\
\hline Self-employed & 0.3 & 4.1 & 92.6 & 1.3 & 1.7 \\
\hline Unemployed & 2.8 & 21.6 & 3.7 & 67.8 & 4.1 \\
\hline Inactive & 1.1 & 6.0 & 2.5 & 1.3 & 89.1 \\
\hline
\end{tabular}

2009

\begin{tabular}{|c|c|c|c|c|c|}
\hline 2008 & Public & Private & -emplc & empl & hactive \\
\hline Public & 91.8 & 2.2 & 0.6 & 2.6 & 2.8 \\
\hline Private & 0.4 & 88.6 & 1.4 & 7.3 & 2.3 \\
\hline Self-employed & 0.2 & 2.2 & 93.3 & 2.4 & 1.9 \\
\hline Unemployed & 3.5 & 20.8 & 3.9 & 70.5 & 1.3 \\
\hline Inactive & 0.8 & 7.0 & 1.7 & 1.3 & 89.2 \\
\hline
\end{tabular}

Source: prepared by the authors on the basis of data from the Social Protection Survey (EPS). 
TABLE 4

\section{Average real hourly wage by sector}

(Pesos at 2009 prices)

\begin{tabular}{lccc}
\hline & \multicolumn{2}{c}{ Sector } & \\
\cline { 2 - 3 } Year & Public & $\begin{array}{r}\text { Private wage- } \\
\text { earning }\end{array}$ & $\begin{array}{c}\text { Percentage difference } \\
\text { betwe public and } \\
\text { private sectors }\end{array}$ \\
\hline 2002 & 2139 & 1422 & 34 \\
2003 & 2150 & 1423 & 34 \\
2004 & 2173 & 1421 & 35 \\
2005 & 2536 & 1509 & 41 \\
2006 & 2502 & 1538 & 39 \\
2007 & 2221 & 1540 & 31 \\
2008 & 2286 & 1570 & 33 \\
2009 & 2366 & 1593 & 31 \\
\hline
\end{tabular}

Source: prepared by the authors on the basis of data from the Social Protection Survey (EPS).

Note: the wage differences are statistically significant at $1 \%$ in all years.

depending on the year, and is statistically significant at the $1 \%$ level. ${ }^{8}$

It should be noted that the analysis of the wage gap does not include self-employed workers, because the EPS reports very low pay rates in this sector compared to those obtained from the CASEN survey - possibly because of the way the income data is requested-. ${ }^{9}$ Whereas the EPS reports that pay for self-employed workers is lower than that of public-sector workers in all deciles of the wage distribution, the CASEN survey shows a significant wage gap in favour of self-employed workers as from the middle deciles.

8 The hourly wage data reported by the CASEN survey in table A.2 of the appendix show some differences in wage levels compared to those of table 2, but a similar wage gap.

9 In the EPS, self-employed workers report their net monthly income or wage and the value of withdrawals of business profits for personal consumption over the last 12 months; whereas the CASEN survey asks about money and the value of amounts withdrawn from the business in the month in question, and business profits over the last 12 months.
Another aspect that is interesting to analyse is the growth of the average hourly wage for different types of workers. The first two columns of table 5 show the growth in real hourly wages for individuals who were in the public sector or the wage-earning private sector in 2002, and who were either in the same sector in 2009 or had moved to the wage-earning private sector or the public sector, correspondingly. The third and fourth columns describe the increase in pay for those who remained in the same sector (workers without mobility) throughout the period (from January 2002 to December 2009). The fifth to eighth columns show the increase in wages for workers that move between these different states of employment (workers with mobility) in the period 2002-2009. The fifth and sixth columns show what happened with workers that rotated between sectors or who were unemployed or inactive in certain months; and the seventh and eighth columns show the growth in wages for workers with mobility who were employed throughout the period under analysis. This latter group therefore refers to workers who moved between the public and private sectors at some point in the period 2002-2009.

Firstly, the data in table 5 show less wage growth for workers employed in the public sector in 2002 and 2009, compared to those employed in the private sector in both years, or those who moved between sectors. Among workers without mobility, private-sector pay during the analysis period grew by $14 \%$ more (36\% compared with $22 \%$ ) than for those who remained in the public sector. This could be related to the more flexible wage-setting practices that exist in the private sector, while public-sector wages are established through a unified pay scale. ${ }^{10}$

\footnotetext{
10 The unified pay scale sets pay levels for public-sector workers according to their hierarchical level, which depends on their experience, training, performance appraisal and knowledge.
}

Real wage growth, 2002-2009

(Percentages)

2009

\begin{tabular}{|c|c|c|c|c|c|c|c|c|}
\hline \multirow{3}{*}{$\begin{array}{l}\text { Year } \\
2002\end{array}$} & \multirow{2}{*}{\multicolumn{2}{|c|}{ Total workers in the sample }} & \multirow{2}{*}{\multicolumn{2}{|c|}{ Workers without mobility }} & \multicolumn{4}{|c|}{ Workers with mobility } \\
\hline & & & & & \multicolumn{2}{|c|}{ Total } & \multicolumn{2}{|c|}{$\begin{array}{l}\text { Employed continuously } \\
\text { throughout the period }\end{array}$} \\
\hline & Public & Private & Public & Private & Public & Private & Public & Private \\
\hline Public & 23 & 39 & 22 & & 50 & 38 & 25 & 39 \\
\hline Private & 38 & 38 & & 36 & 51 & 44 & 38 & 44 \\
\hline
\end{tabular}

Source: prepared by the authors on the basis of data from the Social Protection Survey (EPS). 
The analysis of wage growth for workers with mobility shows that the change in occupational status seems to be linked to larger wage increases. This is reflected in the lower growth seen among those who remained in employment throughout the period, particularly those who were working in the public sector in 2009 (see columns 5 and 7 of table 5). Those who remained employed throughout the period and were in the public sector in 2002 and 2009, but during those years moved between sectors, saw their wages rise by $25 \%$ on average. This is just half of the average increase in wages for public-sector workers in 2009, who at some point before were not employed. Accordingly, this larger wage increase affects individuals that entered and left the labour market, who, according to the data (not reported), are mainly women with fewer years of schooling and a lower hourly wage. This suggests that much of the growth in wages could be explained by composition effects and not necessarily increases in workers' productivity.
Lastly, it is interesting to analyse the different individual characteristics of workers in the public and private sectors, which can be related to individuals' decisions on which sector to work in. Table 6 shows characteristics of public-sector and private-sector wageearning employees around 2009, many of which will be considered in the econometric analysis of section III. To test the statistical significance of the differences, the final column reports a difference-of-means test for each variable between the public and wage-earning private sectors.

The data show that public-sector workers display statistically significant differences with respect to wage-earning private-sector workers in most of the variables shown in table 6. Public-sector employees are characterized by mostly being women, having higher education, paying in to social security, and working in larger productive units. As many as $82 \%$ of publicsector employees work in the community, social and

TABLE 6

Characteristics of workers in the public and wage earning private sector is, 2009

\begin{tabular}{|c|c|c|c|c|c|}
\hline \multirow{2}{*}{ Characteristic } & \multicolumn{2}{|c|}{$\begin{array}{c}\text { Public sector } \\
\text { (826 individuals) }\end{array}$} & \multicolumn{2}{|c|}{$\begin{array}{c}\text { Private sector } \\
\text { (4 } 207 \text { individuals) }\end{array}$} & \multirow{2}{*}{ Difference } \\
\hline & Mean & $\begin{array}{l}\text { Standard } \\
\text { deviation }\end{array}$ & Mean & $\begin{array}{l}\text { Standard } \\
\text { deviation }\end{array}$ & \\
\hline Age & 47.15 & 11.35 & 43.86 & 11.08 & $3.29 * * *$ \\
\hline Male $^{\mathrm{a}}$ & 43 & 49 & 61 & 49 & $-18 * * *$ \\
\hline Years of schooling & 13.25 & 3.74 & 10.88 & 3.66 & $2.37 * * *$ \\
\hline Higher education $^{\mathrm{a}}$ & 50 & 50 & 22 & 41 & $28 * * *$ \\
\hline Married or cohabiting ${ }^{a}$ & 63 & 48 & 61 & 49 & 2 \\
\hline No. of children & 1.64 & 1.20 & 1.60 & 1.29 & 0.04 \\
\hline No. of months employed (since 1980) & 160.21 & 107.34 & 127.00 & 84.70 & $33.21 * * *$ \\
\hline No. of months unemployed (since 1980) & 5.54 & 20.54 & 7.94 & 20.83 & $-2.40 * * *$ \\
\hline No. of months inactive (since 1980) & 13 & 43.62 & 14.82 & 47.30 & -1.82 \\
\hline Job tenure & 89.99 & 108.80 & 54.37 & 68.28 & $35.62 * * *$ \\
\hline Signed contract ${ }^{\mathrm{a}}$ & 91 & 29 & 83 & 37 & $7 * * *$ \\
\hline Union membership & 42 & 49 & 16 & 37 & $26 * * *$ \\
\hline Firm size ( 1 to 3 workers $)^{\mathrm{a}}$ & 3 & 18 & 16 & 36 & $-12 * * *$ \\
\hline Firm size (4 to 9 workers $)^{\mathrm{a}}$ & 4 & 19 & 9 & 29 & $-6 * * *$ \\
\hline Firm size (10 a 24 workers $)^{\mathrm{a}}$ & 10 & 31 & 11 & 31 & 0 \\
\hline Firm size $(25 \text { to } 59 \text { workers })^{\mathrm{a}}$ & 13 & 33 & 11 & 32 & 1 \\
\hline Firm size $(60 \text { to } 119 \text { workers })^{\mathrm{a}}$ & 9 & 28 & 7 & 26 & 1 \\
\hline Firm size (120 or more workers) & 61 & 49 & 46 & 50 & $16 * * *$ \\
\hline Agriculture, hunting, forestry and fishing ${ }^{a}$ & 3 & 16 & 11 & 32 & $-9 * * *$ \\
\hline Mining and quarrying $\mathrm{a}$ & 2 & 14 & 2 & 14 & 0 \\
\hline Manufacturing industries ${ }^{a}$ & 1 & 11 & 13 & 34 & $-12 * * *$ \\
\hline Electricity, gas and water ${ }^{\mathrm{a}}$ & 0 & 0 & 1 & 10 & $-1 * * *$ \\
\hline Construction $^{\mathrm{a}}$ & 4 & 18 & 11 & 32 & $-8 * * *$ \\
\hline Commerce, restaurants and hotels ${ }^{\mathrm{a}}$ & 1 & 12 & 18 & 39 & $-17 * * *$ \\
\hline Transport, storage and communications ${ }^{\mathrm{a}}$ & 2 & 15 & 9 & 28 & $-7 * * *$ \\
\hline Financial establishments, insurance ${ }^{a}$ & 3 & 16 & 9 & 29 & $-7 * * *$ \\
\hline Community, social and personal services ${ }^{\mathrm{a}}$ & 82 & 38 & 23 & 42 & $59 * * *$ \\
\hline Economic sector unknown ${ }^{a}$ & 2 & 13 & 2 & 13 & 0 \\
\hline
\end{tabular}

Source: prepared by the authors on the basis of data from the Social Protection Survey (EPS).

Note:*** significant at $1 \%$.

a Percentages. 
personal services sector. In contrast, wage-earners in the private sector have a lower average education level than their public-sector counterparts, and in 2009 were mainly working in manufacturing (13\%), commerce (18\%), construction (11\%) and community, social and personal services (23\%). Moreover, public-sector employees are more likely than private-sector wageearners to have a contract, and are more likely to be member of a labour union and display less job turnover.
The latter point arises when considering the number of months' service in the job and the number of months employed, unemployed or inactive since 1980. These variables affect the wage dynamic and can be included in the analysis through the longitudinal structure of the data. Public-sector workers also display a longer time of service, more months employed and fewer months unemployed then private-sector wage-earners.

\section{III}

\section{Econometric analysis}

\section{Methodology}

The data described in the previous section reveal the existence of a positive average wage differential between public-sector workers and private-sector wage-earners, along with significant differences in their observable characteristics. In addition, there could be unobservable differences (in innate skills, motivation, risk aversion, among others) that affect the gap. For example, as the transition rate to unemployment is lower for publicsector than for private-sector workers, more risk-adverse individuals are likely to self-select in the public sector.

A correct estimation of the wage gap should be able to isolate the effect of observable and unobservable factors that explain the workers' pay and selection between sectors. ${ }^{11}$ For this purpose, a fixed-effects model is estimated to control for unobserved heterogeneity between individuals that remains invariant through time. ${ }^{12}$

Following the literature that studies the wage gap between the public and private sectors, the following standard specification is estimated:

$$
w_{i t}=\alpha_{i}+\lambda_{t}+\beta \text { Public }_{i t}+\gamma X_{i t}+\varepsilon_{i t}
$$

where $w_{i t}$ is the logarithm of the hourly wage per month of worker " $i$ " on date " $t$ "; $\alpha_{i}$ captures time-invariant factors affecting the wage; $\lambda_{t}$ considers temporary factors by year; "Public" is a dummy variable equal to 1 if worker

\footnotetext{
11 In other words, the decision to work in the public or private sector or to switch from one to the other.

12 In terms of the validity of the specification, the Hausman test rejects the null hypothesis of a lack of correlation between $\alpha_{i}$ and $\varepsilon_{i t}$, so the fixed-effects model allows consistent estimation of the parameters, unlike the random- effects model.
}

"i" is employed in the public sector at time "t", and equal to 0 if the worker is employed in the private sector; $X_{i t}$ is a matrix of individual controls typically used in the literature, relating to demographic characteristics and others related to the worker's productivity. ${ }^{13}$ Lastly, $\varepsilon_{i t}$ it is the error term for which the fixed-effects model provides efficient estimations of the coefficients, provided the errors are not correlated with the other variables included in the estimation.

In estimations using cross-section data, if publicsector workers are more productive than those in the private sector due to unobservable characteristics, and they are rewarded for these characteristics, the unobservable factors will affect the coefficient of the dichotomous variable "Public", and hence the wage gap between the sectors would be overestimated. Nonetheless, working with longitudinal data makes it possible to control for unobservable effects that are constant through time. Thus, specification (1) is identified by comparing the income of individuals who switch sector, controlling for observable characteristics both before and after that change, and assuming that their unobservable characteristics (creativity, intelligence and preferences, for example) are time-invariant.

The fixed effects specification of equation (1) assumes that the unobservable factors are constant

\footnotetext{
13 The following individual controls are specifically included: age, education level, marital status, family composition, real employment experience, and length of service in the job calculated as the number of months that the person appears in the database in the same job. Characteristics related to working conditions include whether the individual contributes to social security, whether he or she has a contract, issues receipts for fees received, or is a member of a union, and the size of the firm in which he or she works.
} 
through time. Although this assumption is technically impossible to prove, its validity is closely related to how similar the individuals who switch sector are, compared to those who remain in the same sector. It is therefore necessary to check that the variable "Public" is independent of the wage and that there is therefore no selection between those who decide to change their sector of work. Specifically, this entails verifying if the following condition holds:

$$
E\left(w_{0, i t} \mid \alpha_{i}, \text { Public, } X_{i t}\right)=E\left(w_{0, i t} \mid \alpha_{i}, X_{i t}\right)
$$

in other words, equation (2) checks that the expected value of the wage before changing sector would have been the same between those who switched and those who did not. This assumption is hard to justify when the group of workers that change sector have very different characteristics from those of workers without inter-sectoral mobility, ${ }^{14}$ which indicates the existence of a selection problem.

An effective way to deal with the selection problem described above requires controlling for differences in the distribution of individual characteristics among workers in the public and private sectors. For that purpose, a propensity-score matching (PSM) procedure is applied, combined with a differences-in-differences (DID) technique. This is used to estimate equation (1) using the common support of the distributions of individual characteristics. That is, the sample used includes workers with similar characteristics who switched sector and those who remained in the same sector. ${ }^{15}$

The PSM matching procedure requires a treatment group and a control group to be defined. For this study, the treatment group consists of workers who move from the private sector to the public sector, and the control group consists of workers who remain employed in the private sector throughout the period of analysis, that is,

\footnotetext{
14 Table 7 below shows the differences in observable characteristics between workers who switch from the private to the public sector, and those who remain in the private sector throughout the period of analysis. In most of the characteristics considered, these two groups display statistically significant differences. A similar pattern is observed between those workers who move from the public to the private sector, and those who remain in the public sector. The latter results are available upon request from the authors, but are not reported in this document because they will not be considered in the matching procedure.

15 Similar matching procedures have been used in other studies in different fields. See for example, Arráiz, Henríquez and Stucchi (2013); Castillo and others (2013).
}

who never change sector. ${ }^{16}$ Basically, the aim of this exercise is to gauge the extent to which switching from the private to the public sector involves wage changes not related to individual's characteristics. ${ }^{17}$

The following subsection presents the fixed effects estimations and explains and discusses the results of the matching procedure implemented.

\section{Results}

The estimations presented below are based on a small sample which excludes individuals that were self-employed workers at any time during the period analysed. This is due to the measurement problem described before in the dependent variable "income" and the fact that very few public-sector workers have ever been self-employed in the full sample. ${ }^{18}$ Moreover, according to Panizza and Qiang (2005), all the models are estimated for men (women) who initially were between 18 and 65 (60) years old, because it is less common for people to work beyond retirement age in the public sector. ${ }^{19}$

The sample used corresponds, then, to an unbalanced panel of 5,478 individuals in the period spanning January 2002 to December 2009. The descriptive statistics for the complete sample (9,306 observations) and the reduced sample (5,478 observations) are shown in table A. 3 of the appendix. In general, the reduced sample is quite similar to the full sample in terms of personal characteristics; nonetheless, the workers of the reduced sample have more time in the same job, and a larger proportion of them contribute to social security, have a contract, participate in a union and work in larger firms. These patterns are in line with the characteristics of public-sector workers shown in table 6.

Columns 1 and 2 of table 9 present the results of the estimations of the wage gap with the fixed-effects model under two specifications. The first corresponds to the estimation of equation (1) with the variables described above; and the second also includes the interaction

\footnotetext{
16 The PSM procedure was also carried out by defining the treatment group as individuals who change from the public to the private sector, and the control group as those who remain in the public sector. The results are not shown because it was impossible to eliminate the pre-treatment heterogeneity between the groups based on observable characteristics. This is partly due to the small number of observations in the control group in the sample.

17 Pratap and Quintin (2006) implement matching techniques to estimate the wage gap between the formal and informal sectors in Argentina.

18 This implies that 3,329 individuals were dropped from the original sample.

19 This implies that 499 individuals were dropped from the original sample.
} 
between years and the public sector dummy variable to explore whether the average wage gap changed during the period analysed. The data show that the average wage disappears once observable and unobservable characteristics are controlled for ${ }^{20}$ This result is consistent with the findings of Bargain and Melly (2008) for France, who use longitudinal data; and it is also in line with the results reported by Mizala, Romaguera and Gallegos (2011) for Chile, comparing public- and private-sector employees, excluding self-employed workers. In addition, the estimated average wage gap seems constant in the period analysed, given that the marginal effect of the public-sector variable "Public" by year is not statistically different from zero (0).

Lastly, one of the advantages of using longitudinal data is the greater availability of information on employment history that could affect wages. The results show that job tenure (number of months), work experience, having a signed contract, issuing fee receipts, and participating in a labour union have a positive effect on the wage. This last result is consistent with the typical rent-seeking mechanisms of unions.

As noted at the start of this section, as the fixedeffects model is estimated using a sample of persons with different observable characteristics, this could bias the estimations through the selection of workers in the public and private sectors. To alleviate this problem, a PSM procedure was implemented, as described below, to calculate the average impact between a subsample of individuals who are matched according to their observable characteristics. Additionally, individuals in the common support of the PSM are considered in order to estimate the fixed-effects model, thereby reducing selection bias. In this exercise, the treatment is defined as the change of status from being employed in the private sector to being employed in the public sector. Application of the PSM procedure, combined with a DID technique, makes it possible to control for workers' observable and unobservable characteristics, which would affect their decision to switch from the private to the public sector (propensity score) and the trend of the result variable (in this case the wage) in the absence of treatment (Heckman and Hotz, 1989; Blundell and Costa Dias, 2000).

The main identification assumption of the DID estimator is that, in the absence of treatment, there are no wage differences between workers in the control

${ }^{20}$ For comparison, the model was estimated using pooled OLS, and this found a significant premium of $0.4 \%$ in favour of publicsector workers. group and those in the treatment group. In other words, there are no wage differences between those who change from the private to the public sector and those who stay in the private sector. Accordingly, PSM restricts the estimation sample to the common support of the distribution of the observable characteristics of the two groups.

The method applied consists firstly of estimating the probability of switching employment from the private sector to the public sector. In the next stage, observations from the treatment group (individuals who change sector) are matched with those from control group, to make the likelihood of changing sector as similar as possible. There are different ways of implementing the PSM model, and, in general, the results may depend on the matching assumption and the variables considered in the estimation of the probability of changing from the private sector to the public sector. This study matched the observations using the nearest-neighbour method. ${ }^{21}$ According to Caliendo and Kopeinig (2008), this method is the most conservative and appropriate when there is a large number of observations to form part of the control group, as is the case in this study. ${ }^{22}$ Nonetheless, while the nearest-neighbour method is the most appropriate in terms of reducing biases, this comes at a cost of less efficiency because it uses a control group that is the same size as the treatment group. Lastly, with matched observations, the effect on the average wage of changing from a private-sector job to employment in the public sector is estimated. The results of the different stages of the matching procedure are described in detail below.

Using the data on individuals who are always employed in the public or private sectors throughout the sample period, the probability of changing from the private sector to the public sector was estimated on the basis of personal characteristics not affected by the treatment, and year dummy variables. Table A.4 of the appendix shows the results of the Probit estimation of the likelihood of switching employment from the private sector the public sector. These show a low probability of changing sector in the case of men, which is consistent with the larger proportion of women working in the public sector. There is also a positive effect from the

21 As a robustness exercise, the matching was performed using five nearest neighbours and also on the basis of minimization of the Mahalanobis distance. The results were very similar to those obtained from the matching based on one nearest neighbour.

22 With a large number of observations in the control group, there is a greater chance of finding observations with a similar likelihood of changing sector between the treatment and control samples. 
years of schooling variable, and from the fact that either the father or mother works and has higher education. ${ }^{23}$

Figure 1 shows the probability distribution of switching from the private to the public sector for the control group and treatment group in the common support. Both distributions are very similar after the matching. To test the general quality of the matching procedure, the pseudo $\mathrm{R}^{2}$ of the Probit model was used - which falls from 0.1296 before the matching to 0.01 in the matched sample; and the likelihood ratio test, which rejects the null hypothesis of joint lack of significance of the Probit explanatory variables in the original sample at the $1 \%$ confidence level, but does not reject that hypothesis in the matched sample.

The quality of the matching procedure can be further tested by checking whether the characteristics included in the Probit estimation of table A.4 in the appendix are similar between the treatment and control groups after the PSM procedure. This test is usually referred to as the "balance test". Table 7 shows the average value of each variable for each group, and the result of a difference-inmeans test on the original sample (the reduced sample described above) and in the matched sample. As can be seen, although there are significant differences in many of the variables before matching, after the matching

23 These two variables are not included in the fixed-effects model estimation because they do not vary across individuals through time. procedure it is impossible to reject the null hypothesis of equal means in any of the variables considered, most of which display significant differences in the original sample. All of this suggests that the quality of the matching procedure implemented is acceptable.

Once the PSM procedure has been implemented, and having made sure that the sample contains similar workers in both groups, the next step is to test the fundamental assumption of the DID method, that in the absence of treatment (in this case, mobility from the private sector the public sector), the wage would be the same in the control group and in the treatment group. Although this counterfactual cannot be tested, Heckman and Hotz (1989) suggest evaluating the effect of treatment on the result variable before it is carried out. If the wages are the same for both groups before treatment, one can then assume that the wages of the two groups would remain the same in the absence of treatment. Lastly, the estimator of the average effect is calculated using the DID method. ${ }^{24}$

Table 8 presents the results. It firstly reports a difference-in-means test for wages between the groups before treatment $(\mathrm{t}-1)$, in the sample before and after matching. Lastly, it reports the average effect of the

24 The average impact is calculated using the following formula: $\mathrm{E}\left(\mathrm{Y}_{\mathrm{T}, 1}-\mathrm{Y}_{\mathrm{T}, 0} \mid \mathrm{T}_{1}=1\right)-\mathrm{E}\left(\mathrm{Y}_{\mathrm{C}, 1}-\mathrm{Y}_{\mathrm{C}, 0} \mid \mathrm{T}_{1}=0\right)$, where $\mathrm{T}_{1}$ denotes the treatment variable (in this case, moving from a wage-earning job in the private sector to employment in the public sector).

FIGURE 1

Probability distribution of changing from the private sector to the public sector after matching

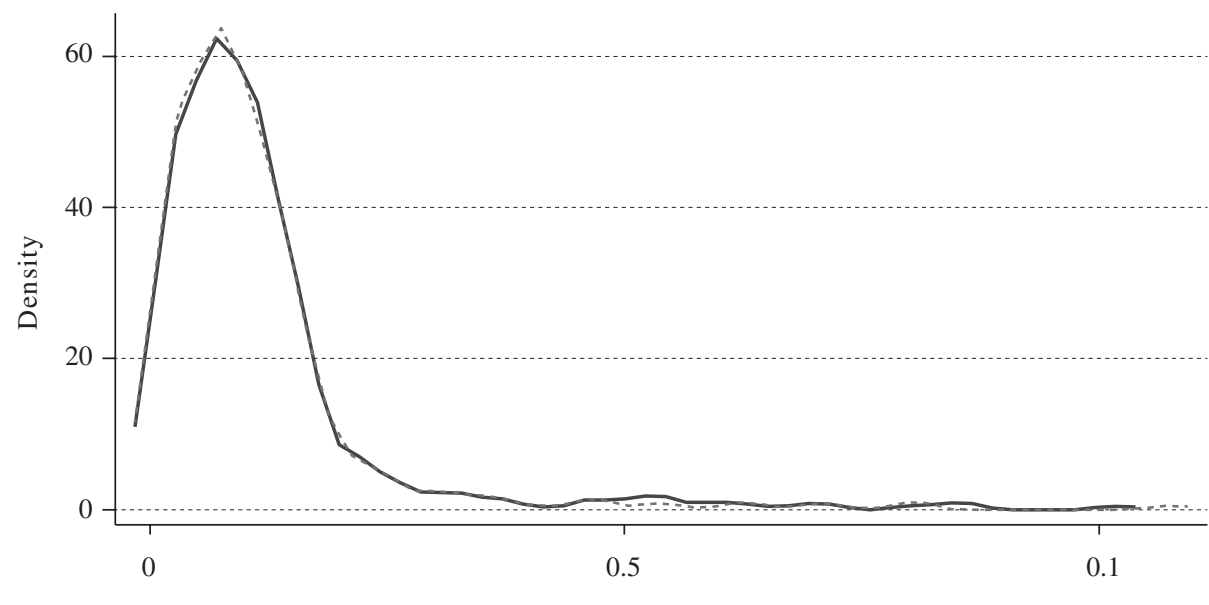

Probability of employment in the public sector

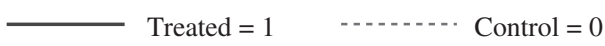

Source: prepared by the authors. 
TABLE 7

Observable differences in mean before and after matching

\begin{tabular}{|c|c|c|c|c|c|}
\hline \multirow{2}{*}{ Variable } & \multirow{2}{*}{ Sample } & \multicolumn{2}{|c|}{ Mean } & \multirow{2}{*}{ t-test } & \multirow{2}{*}{$\mathrm{p}>|\mathrm{t}|$} \\
\hline & & Treatment & Control & & \\
\hline \multirow[t]{2}{*}{ Male } & Original & 0.536 & 0.678 & -6.21 & 0.00 \\
\hline & Matched & 0.536 & 0.567 & -0.90 & 0.37 \\
\hline \multirow{2}{*}{ Age } & Original & 41.552 & 42.245 & -1.36 & 0.18 \\
\hline & Matched & 41.552 & 41.717 & -0.22 & 0.83 \\
\hline \multirow{2}{*}{ Married or cohabiting } & Original & 0.590 & 0.668 & -3.39 & 0.00 \\
\hline & Matched & 0.590 & 0.598 & -0.21 & 0.83 \\
\hline \multirow[t]{2}{*}{ Years of schooling } & Original & 12.043 & 10.631 & 7.96 & 0.00 \\
\hline & Matched & 12.043 & 11.831 & 0.87 & 0.39 \\
\hline \multirow[t]{2}{*}{ No of household members } & Original & 5.231 & 4.894 & 3.23 & 0.00 \\
\hline & Matched & 5.231 & 5.102 & 0.80 & 0.43 \\
\hline \multirow[t]{2}{*}{ Children between 0 and 2 years of age } & Original & 0.157 & 0.145 & 0.68 & 0.50 \\
\hline & Matched & 0.157 & 0.195 & -1.45 & 0.15 \\
\hline \multirow[t]{2}{*}{ Children between 3 and 5 years of age } & Original & 0.181 & 0.175 & 0.31 & 0.75 \\
\hline & Matched & 0.181 & 0.181 & 0.00 & 1.00 \\
\hline \multirow[t]{2}{*}{ Father/mother works } & Original & 0.102 & 0.024 & 10.29 & 0.00 \\
\hline & Matched & 0.102 & 0.102 & 0.00 & 1.00 \\
\hline \multirow[t]{2}{*}{ Father/mother with higher education } & Original & 0.021 & 0.002 & 8.69 & 0.00 \\
\hline & Matched & 0.021 & 0.031 & -0.86 & 0.39 \\
\hline \multirow[t]{2}{*}{ Year 2002} & Original & 0.007 & 0.131 & -7.52 & 0.00 \\
\hline & Matched & 0.007 & 0.017 & -1.27 & 0.20 \\
\hline \multirow[t]{2}{*}{ Year 2003} & Original & 0.021 & 0.133 & -6.74 & 0.00 \\
\hline & Matched & 0.021 & 0.017 & 0.50 & 0.61 \\
\hline \multirow[t]{2}{*}{ Year 2004} & Original & 0.019 & 0.133 & -6.88 & 0.00 \\
\hline & Matched & 0.019 & 0.014 & 0.54 & 0.59 \\
\hline \multirow[t]{2}{*}{ Year 2005} & Original & 0.464 & 0.133 & 19.93 & 0.00 \\
\hline & Matched & 0.464 & 0.469 & -0.14 & 0.89 \\
\hline \multirow[t]{2}{*}{ Year 2006} & Original & 0.126 & 0.133 & -0.41 & 0.68 \\
\hline & Matched & 0.126 & 0.107 & 0.86 & 0.39 \\
\hline \multirow[t]{2}{*}{ Year 2007} & Original & 0.317 & 0.132 & 11.10 & 0.00 \\
\hline & Matched & 0.317 & 0.343 & -0.81 & 0.42 \\
\hline \multirow[t]{2}{*}{ Year 2008} & Original & 0.021 & 0.132 & -6.71 & 0.00 \\
\hline & Matched & 0.021 & 0.019 & 0.24 & 0.81 \\
\hline \multicolumn{6}{|l|}{ No. of individuals in the common support } \\
\hline Treated & \multicolumn{5}{|c|}{416} \\
\hline Controls & \multicolumn{5}{|c|}{1522} \\
\hline
\end{tabular}

Source: prepared by the authors.

TABLE 8

Test of wage equality before treatment and the effect of treatment on the treated

\begin{tabular}{|c|c|c|c|c|c|c|}
\hline \multirow[t]{2}{*}{ Logarithm of the monthly hourly wage } & \multirow{2}{*}{ Sample } & \multicolumn{3}{|c|}{ Mean } & \multirow{2}{*}{ t-test } & \multirow{2}{*}{$\mathrm{p}>|\mathrm{t}|$} \\
\hline & & Treated & Control & Difference & & \\
\hline \multirow[t]{2}{*}{ Before treatment $(\mathrm{t}-1)$} & Original & 3133 & 3118 & 0.015 & 0.80 & 0.43 \\
\hline & Matched & 3133 & 3157 & -0.024 & -0.90 & 0.37 \\
\hline \multirow[t]{2}{*}{ Treatment month (t) } & Original & 3165 & 3119 & 0.046 & 3.20 & 0.00 \\
\hline & Matched & 3165 & 3165 & 0.000 & 0.00 & 1.00 \\
\hline \multirow[t]{2}{*}{1 month after treatment $(\mathrm{t}+1)$} & Original & 3172 & 3119 & 0.053 & 3.43 & 0.00 \\
\hline & Matched & 3172 & 3168 & 0.003 & 0.16 & 0.87 \\
\hline \multirow[t]{2}{*}{6 months after treatment $(\mathrm{t}+6)$} & Original & 3168 & 3118 & 0.050 & 3.03 & 0.00 \\
\hline & Matched & 3168 & 3172 & -0.004 & -0.17 & 0.86 \\
\hline
\end{tabular}

Source: prepared by the authors. 
treatment on the treated in the treatment month $(\mathrm{t})$, in the following month $(t+1)$ and then six months later $(t+6)$.

The results of the ex-ante equality-of-means test show that, both in the original and in the matched sample, there are no wage differences between individuals in the control group and those who move from the private to the public sector. This result strengthens the validity of the PSM procedure described, because it suggests that the assumption of equation (2) as specified above is satisfied. In terms of the effect of employment mobility towards the public sector, the results report a wage gain of around 5\% for private-sector employees who take a job in the public sector in the original sample, but the gain falls to zero in the matched sample.

Lastly, table 9 uses the results of the matching model, and in columns 3 and 4 presents the results of the estimation of equation (1) in the common-support sample, obtained by estimating the probability of switching from the private to the public sector. ${ }^{25}$ Columns 1 and 2 show the results of the model in the original sample,

25 Does not correspond to the matched observations but to all of the observations in the common support. described above. In general terms, the results for different explanatory variables are similar in the two samples. In terms of the public-private wage differential, the results in the common support sample continue to show that the average wage difference between workers in the treatment group and those in the control group is not different from zero when selection and time-invariant unobservable characteristics are controlled for. ${ }^{26}$

In short, the different exercises described in this section consistently suggest that the unexplained wage gap between workers in the public and private sectors is not statistically different from zero (0), after controlling for the effect of observable and time-invariant unobservable factors and selection.

26 Nonetheless, for 2005 and 2006 a significant gap appears of around $2.5 \%$ in favour of the public sector, at confidence levels of $90 \%$ and $95 \%$ respectively. As noted above, during those years transitions between the public sector and the private wage-earning sector increased considerably, which could be related to the implementation of the Public Senior Management Law and the change in government. From that standpoint, the results suggest the existence of a significant wage differential in favour of the public sector among individuals who switched sector in those years in particular; but they do not provide conclusive evidence of a gap in average wages between the sectors.

TABLE 9

Marginal effects of the fixed-effects model

\begin{tabular}{|c|c|c|c|c|}
\hline & \multicolumn{2}{|c|}{ Original sample } & \multicolumn{2}{|c|}{ Common support } \\
\hline & (1) & (2) & (1) & (2) \\
\hline Public sector (base model) & $\begin{array}{c}0.0082 \\
(0.0080)\end{array}$ & & $\begin{array}{c}0.0154 \\
(0.0125)\end{array}$ & \\
\hline Public sector 2002 & & $\begin{array}{c}0.0136 \\
(0.0117)\end{array}$ & & $\begin{array}{c}0.0154 \\
(0.0363)\end{array}$ \\
\hline Public sector 2003 & & $\begin{array}{c}0.0109 \\
(0.0120)\end{array}$ & & $\begin{array}{c}0.0170 \\
(0.0273)\end{array}$ \\
\hline Public sector 2004 & & $\begin{array}{c}0.0138 \\
(0.0111)\end{array}$ & & $\begin{array}{c}0.0258 \\
(0.0183)\end{array}$ \\
\hline Public sector 2005 & & $\begin{array}{c}0.0083 \\
(0.0097)\end{array}$ & & $\begin{array}{c}0.0248^{*} \\
(0.0136)\end{array}$ \\
\hline Public sector 2006 & & $\begin{array}{c}0.0059 \\
(0.0098)\end{array}$ & & $\begin{array}{l}0.0284 * * \\
(0.0138)\end{array}$ \\
\hline Public sector 2007 & & $\begin{array}{c}0.0053 \\
(0.0086)\end{array}$ & & $\begin{array}{c}0.0021 \\
(0.0119)\end{array}$ \\
\hline Public sector 2008 & & $\begin{array}{c}0.0061 \\
(0.0089)\end{array}$ & & $\begin{array}{c}0.0060 \\
(0.0124)\end{array}$ \\
\hline Public sector 2009 & & $\begin{array}{c}0.0052 \\
(0.0088)\end{array}$ & & $\begin{array}{c}0.0077 \\
(0.0126)\end{array}$ \\
\hline Age & $\begin{array}{l}0.0160^{* * * *} \\
(0.0021)\end{array}$ & $\begin{array}{l}0.0159 * * * \\
(0.0020)\end{array}$ & $\begin{array}{l}0.0122 * * * \\
(0.0031)\end{array}$ & $\begin{array}{l}0.0121^{* * * *} \\
(0.0036)\end{array}$ \\
\hline $\mathrm{Age}^{2}$ & $\begin{array}{l}-0.0002 * * * \\
(0.0000)\end{array}$ & $\begin{array}{l}-0.0002 * * * \\
(0.0000)\end{array}$ & $\begin{array}{l}-0.0001 * * * \\
(0.0000)\end{array}$ & $\begin{array}{l}-0.0001 * * * \\
(0.0000)\end{array}$ \\
\hline Married or cohabiting & $\begin{array}{l}-0.0009 \\
(0.0060)\end{array}$ & $\begin{array}{l}-0.0008 \\
(0.0061)\end{array}$ & $\begin{array}{c}0.0076 \\
(0.0097)\end{array}$ & $\begin{array}{c}0.0077 \\
(0.0094)\end{array}$ \\
\hline Years of schooling & $\begin{array}{l}0.0064 * * * \\
(0.0023)\end{array}$ & $\begin{array}{l}0.0065^{* * *} \\
(0.0024)\end{array}$ & $\begin{array}{l}0.0065^{* *} \\
(0.0028)\end{array}$ & $\begin{array}{l}0.0065^{* *} \\
(0.0026)\end{array}$ \\
\hline No. of household members & $\begin{array}{c}(0.0025) \\
0.0033 \\
(0.0025)\end{array}$ & $\begin{array}{c}(0.0024) \\
0.0032 \\
(0.0027)\end{array}$ & $\begin{array}{l}(0.0028) \\
-0.0007 \\
(0.0041)\end{array}$ & $\begin{array}{l}(0.0020) \\
-0.0008 \\
(0.0035)\end{array}$ \\
\hline
\end{tabular}


Table 9 (conclusion)

\begin{tabular}{|c|c|c|c|c|}
\hline & \multicolumn{2}{|c|}{ Original sample } & \multicolumn{2}{|c|}{ Common support } \\
\hline & (1) & (2) & (1) & (2) \\
\hline \multirow[t]{2}{*}{ Children between 0 and 2 years of age } & $0.0094 *$ & 0.0093 & $0.0181 * *$ & $0.0181^{* * *}$ \\
\hline & $(0.0051)$ & $(0.0063)$ & $(0.0086)$ & $(0.0068)$ \\
\hline \multirow[t]{2}{*}{ Children between 3 and 5 years of age } & 0.0037 & 0.0036 & 0.0065 & 0.0064 \\
\hline & $(0.0044)$ & $(0.0049)$ & $(0.0079)$ & $(0.0080)$ \\
\hline \multirow[t]{2}{*}{ Work experience (since 1980) } & $0.0087 * * *$ & $0.0088 * * *$ & $0.0090 * * *$ & $0.0093 * * *$ \\
\hline & $(0.0011)$ & $(0.0012)$ & $(0.0021)$ & $(0.0016)$ \\
\hline \multirow[t]{2}{*}{ Work experience (since 1980) ${ }^{2}$} & $-0.0001 * *$ & $-0.0001 * *$ & -0.0001 & $-0.0001 * *$ \\
\hline & $(0.0000)$ & $(0.0000)$ & $(0.0001)$ & $(0.0001)$ \\
\hline \multirow[t]{2}{*}{ Time in job } & $0.0046^{* * *}$ & $0.0046 * * *$ & 0.0022 & 0.0023 \\
\hline & $(0.0013)$ & $(0.0014)$ & $(0.0019)$ & $(0.0022)$ \\
\hline \multirow[t]{2}{*}{ Time in job ${ }^{2}$} & $-0.0002 * * *$ & $-0.0002 * * *$ & -0.0001 & -0.0001 \\
\hline & $(0.0001)$ & $(0.0001)$ & $(0.0001)$ & $(0.0001)$ \\
\hline \multirow[t]{2}{*}{ Contributes to social security } & 0.0124 & 0.0124 & 0.0149 & 0.0151 \\
\hline & $(0.0078)$ & $(0.0095)$ & $(0.0148)$ & $(0.0127)$ \\
\hline \multirow[t]{2}{*}{ Signed contract } & $0.0303 * * *$ & $0.0303 * * *$ & 0.0194 & 0.0192 \\
\hline & $(0.0085)$ & $(0.0097)$ & $(0.0150)$ & $(0.0122)$ \\
\hline \multirow[t]{2}{*}{ Fees } & $0.0228 * *$ & $0.0228 * *$ & $0.0223 *$ & $0.0225^{*}$ \\
\hline & $(0.0089)$ & $(0.0089)$ & $(0.0123)$ & $(0.0127)$ \\
\hline \multirow[t]{2}{*}{ Union membership } & $0.0210 * * *$ & $0.0213 * * *$ & $0.0246 * * *$ & $0.0244 * *$ \\
\hline & $(0.0074)$ & $(0.0056)$ & $(0.0091)$ & $(0.0103)$ \\
\hline No. of observations & 351277 & 351277 & 161796 & 161796 \\
\hline No. of individuals & 5417 & 5417 & 1934 & 1934 \\
\hline $\mathrm{R}^{2}$ & 0.1828 & 0.1829 & 0.1697 & 0.1715 \\
\hline
\end{tabular}

Source: prepared by the authors.

Note: standard errors calculated through the bootstrap method in parentheses.

All specifications include dummies by year and by firm size. The specifications of columns 2 and 4 include interactions of the "public sector" variable and the annual dummy variables. The table only reports the marginal effects of the "public sector" variable in each specification, and not the interaction coefficients.

$* \mathrm{p}<0,10 ; * * \mathrm{p}<0,05 ; * * * \mathrm{p}<0,01$.

\section{IV}

\section{Conclusions}

The key objective of this paper was to study wage differences and worker mobility among wage-earners in the public and private sectors in Chile, using longitudinal data obtained from the Social Protection Survey (EPS) for the period 2002-2009.

The descriptive analysis of the data show that, during the period analysed, between $10 \%$ and $12 \%$ of employed workers were working in the public sector; and, depending on the year, the average hourly wage in the public sector was between $31 \%$ and $41 \%$ higher than in wage-earning employment in the private sector. Moreover the most common turnover of workers occurred within the private sector (between wage-earning jobs in the private sector and self-employment); nonetheless, between $5 \%$ and $30 \%$ of public-sector workers changed status in any given year, moving mainly into wage-earning jobs in the private sector. There is also significantly less chance of becoming unemployed or inactive in the long-term from the public than from the private sector.

Taking advantage of the longitudinal structure of the data, the average wage differential between the public sector and the wage-earning private sector was estimated using a fixed-effects model and including employment history variables that are usually omitted in cross-section databases. In addition, a matching technique was implemented between public and private sector workers, to estimate the fixed-effects model for a sample of individuals that have a distribution of similar observable characteristics, and thus reduce the selection bias that could be present in the original 
fixed-effects estimation. The results show that the average wage differential observed in the descriptive statistics is caused by worker selection in the private or public sectors, because when the comparison is restricted to a subsample of workers with similar characteristics, the premium disappears. These results are consistent with those found in other international studies that use panel data; and they highlight the importance of correcting for selection in terms of time-invariant observable and unobservable factors to measure the inter-sectoral wage differential.

As a future extension of the analysis presented here, it would be interesting to use these panel data to estimate the distribution of the wage gap between the public and private sectors in Chile, controlling for workers' observable and unobservable characteristics. 
APPENDIX

TABLE A.1

Distribution of the employed labour force by sector, 2000-2009

(Percentages)

\begin{tabular}{|c|c|c|c|c|}
\hline \multirow{2}{*}{ Year } & \multicolumn{3}{|c|}{ Sector } & \multirow{2}{*}{ Total } \\
\hline & Public & Private wage-earning & Private self-employed & \\
\hline 2000 & 12.0 & 63.8 & 24.2 & 100 \\
\hline 2003 & 10.8 & 64.8 & 24.4 & 100 \\
\hline 2006 & 9.9 & 66.5 & 23.6 & 100 \\
\hline 2009 & 11.7 & 65.0 & 23.3 & 100 \\
\hline
\end{tabular}

Source: prepared by the authors on the basis of data from the National Socioeconomic Survey (CASEN) of the Ministry of Social Development of Chile.

TABLE A.2

Real hourly wage by sector, 2000-2009

(Pesos at 2009 prices)

\begin{tabular}{lccc}
\hline & \multicolumn{2}{c}{ Sector } & \multicolumn{2}{c}{$\begin{array}{c}\text { Percentage difference between } \\
\text { public } \\
\text { year }\end{array}$} & Public & Private wage-earning & 32 \\
\cline { 2 - 3 } & 2526 & 1717 & 37 \\
2000 & 2704 & 1695 & 35 \\
2006 & 2481 & 1600 & 36 \\
2009 & 3175 & 2019 & 36 \\
\hline
\end{tabular}

Source: prepared by the authors on the basis of data from the National Socioeconomic Survey (CASEN) of the Ministry of Social Development of Chile.

Note: the wage differences are statistically significant at $1 \%$ in all years. 
Descriptive statistics: complete sample and reduced sample

\begin{tabular}{|c|c|c|c|c|}
\hline & \multicolumn{2}{|c|}{$\begin{array}{c}\text { Complete sample } \\
\text { (No. of observations: } 9 \text { 306) }\end{array}$} & \multicolumn{2}{|c|}{$\begin{array}{c}\text { Reduced sample } \\
\text { (No. of observations: } 5 \text { 748) }\end{array}$} \\
\hline & Mean & $\begin{array}{l}\text { Standard } \\
\text { deviation }\end{array}$ & Mean & $\begin{array}{l}\text { Standard } \\
\text { deviation }\end{array}$ \\
\hline Age & 43.53 & 13.12 & 41.34 & 11.65 \\
\hline Male $^{\mathrm{a}}$ & 56 & 50 & 50 & 50 \\
\hline Higher education $^{\mathrm{a}}$ & 19 & 39 & 22 & 42 \\
\hline Married or cohabiting ${ }^{\mathrm{a}}$ & 62 & 49 & 61 & 49 \\
\hline No. of children & 1.55 & 1.30 & 1.57 & 1.27 \\
\hline Public sector ${ }^{\mathrm{a}}$ & 8 & 28 & 13 & 33 \\
\hline Private sector $^{\mathrm{a}}$ & 47 & 50 & 63 & 48 \\
\hline Self-employed sector ${ }^{a}$ & 19 & 39 & 0 & 0 \\
\hline Unemployed $^{\mathrm{a}}$ & 10 & 30 & 11 & 31 \\
\hline No. of months employed (since 1980) & 125.16 & 98.19 & 122.78 & 94.58 \\
\hline No. of months unemployed (since 1980) & 10.65 & 25.85 & 11.14 & 25.49 \\
\hline No. of months inactive (since 1980) & 25.64 & 59.69 & 23.82 & 56.92 \\
\hline Job tenure & 78.63 & 89.01 & 85.16 & 90.23 \\
\hline Signed contract ${ }^{\mathrm{a}}$ & 62 & 48 & 86 & 34 \\
\hline Logarithm of hourly wage & 3.06 & 0.32 & 3.09 & 0.29 \\
\hline Contributes to social security ${ }^{\mathrm{a}}$ & 53 & 50 & 66 & 47 \\
\hline Union membership ${ }^{a}$ & 15 & 36 & 20 & 40 \\
\hline Firm size ( 1 to 3 workers $)^{a}$ & 22 & 42 & 10 & 30 \\
\hline Firm size (4 to 9 workers $)^{\mathrm{a}}$ & 7 & 25 & 6 & 25 \\
\hline Firm size (10 to 24 workers $)^{\mathrm{a}}$ & 7 & 25 & 8 & 28 \\
\hline Firm size (25 to 59 workers $)^{\mathrm{a}}$ & 7 & 26 & 9 & 29 \\
\hline Firm size (60 to 119 workers $)^{\mathrm{a}}$ & 5 & 21 & 6 & $24 \%$ \\
\hline Firm size (120 or more workers $)^{\mathrm{a}}$ & 20 & 40 & 26 & 44 \\
\hline Manufacturing industries ${ }^{\mathrm{a}}$ & 13 & 33 & 13 & 34 \\
\hline Electricity, gas and water ${ }^{\mathrm{a}}$ & 1 & 8 & 1 & 9 \\
\hline Construction $^{\mathrm{a}}$ & 10 & 30 & 8 & 28 \\
\hline Commerce, restaurants and hotels ${ }^{\mathrm{a}}$ & 20 & 40 & 16 & 36 \\
\hline Transport, storage and communications ${ }^{\mathrm{a}}$ & 8 & 26 & 7 & 25 \\
\hline Financial establishments, insurance ${ }^{\mathrm{a}}$ & 6 & 25 & 7 & 26 \\
\hline Community, social and personal services ${ }^{\mathrm{a}}$ & 27 & 45 & 34 & 47 \\
\hline Economic sector unknown ${ }^{\mathrm{a}}$ & 1 & 10 & 1 & 10 \\
\hline
\end{tabular}

Source: prepared by the authors.

a Percentages. 
Probit of the probability of switching employment from the private sector to the public sector

\begin{tabular}{|c|c|c|c|c|}
\hline & Coefficient & Standard error & $\mathrm{Z}$ & $\mathrm{P}>|\mathrm{z}|$ \\
\hline Male & -0.1600 & 0.0378 & -4.23 & 0.00 \\
\hline Age & 0.0023 & 0.0019 & 1.22 & 0.22 \\
\hline Married or cohabiting & -0.0589 & 0.0392 & -1.50 & 0.13 \\
\hline Years of schooling & 0.0378 & 0.0054 & 6.99 & 0.00 \\
\hline No. of household members & 0.0264 & 0.0083 & 3.17 & 0.00 \\
\hline Children between 0 and 2 years of age & 0.0149 & 0.0517 & 0.29 & 0.77 \\
\hline Children between 3 and 5 years of age & 0.0169 & 0.0480 & 0.35 & 0.73 \\
\hline Father/mother works & 0.5623 & 0.0738 & 7.61 & 0.00 \\
\hline Father/mother with higher education & 0.3352 & 0.1741 & 1.93 & 0.05 \\
\hline Year 2002 & -0.4480 & 0.1804 & -2.48 & 0.01 \\
\hline Year 2003 & -0.1725 & 0.1379 & -1.25 & 0.21 \\
\hline Year 2004 & -0.2048 & 0.1406 & -1.46 & 0.15 \\
\hline Year 2005 & 0.8332 & 0.1007 & 8.27 & 0.00 \\
\hline Year 2006 & 0.3541 & 0.1071 & 3.31 & 0.00 \\
\hline Year 2007 & 0.6658 & 0.1017 & 6.55 & 0.00 \\
\hline Year 2008 & -0.1955 & 0.1354 & -1.44 & 0.15 \\
\hline Constant & -3.6835 & 0.1683 & -21.88 & 0.00 \\
\hline No. of observations & \multirow{2}{*}{\multicolumn{4}{|c|}{$\begin{array}{r}137613 \\
0.1296\end{array}$}} \\
\hline Pseudo $\mathrm{R}^{2}$ & & & & \\
\hline
\end{tabular}

Source: prepared by the authors.

Note: the dependent variable is a dummy variable that takes the value 1 if the individual changes from the private sector to the public sector, and 0 otherwise. The sample includes employed workers who change from the private sector to the public sector and workers who are employed throughout the sample period and do not change sector.

\section{Bibliography}

Arráiz, I., F. Henríquez and R. Stucchi (2013), "Supplier development programs and firm performance: evidence from Chile", Small Business Economics, vol. 41, No. 1, Springer.

Bargain, O. and B. Melly (2008), "Public sector pay gap in France: new evidence using panel data", IZA Discussion Papers, No. 3427, Bonn, Institute for the Study of Labor.

Bender, K.A. and R.F. Elliott (1999), "Relative earnings in the UK public sector: the impact of pay reform on pay structure", Public Sector Pay Determination in the European Union, R. Elliott, C. Lucifora and D. Meurs, Houndmills, Macmillan Press.

Blundell, R. and M. Costa Dias (2000), "Evaluation methods for non-experimental data", Fiscal Studies, vol. 21, No. 4, Wiley.

Caliendo, M. and S. Kopeinig (2008), "Some practical guide for the implementation of propensity score matching", Journal of Economic Surveys, vol. 22, No. 1, Wiley.

Castillo, V. and others (2013), "The effect of innovation policy on SMEs' employment and wages in Argentina", Small Business Economics, Springer, April.

Disney, R. and A. Gosling (2008), "Changing public sector wage differentials in the UK", IFs Working Paper, No. 08/02, London, Institute for Fiscal Studies.

Gregory, R. and J. Borland (1999), "Recent development in public sector labor markets", Handbook of Labor Economics, O. Ashenfelter and R. Layard, Amsterdam, North Holland.

Heckman, J. and V. Hotz (1989), "Choosing among alternative nonexperimental methods for estimating the impact of social programs: the case of manpower training", Journal of the American Statistical Association, vol. 84, No. 408, Taylor \& Francis.

Koenker, R. (2004), "Quantile regression for longitudinal data", Journal of Multivariate Analysis, vol. 91, No. 1, Amsterdam, Elsevier.

Krueger, A. (1988), "Are public sector workers paid more than their alternative wage? Evidence from longitudinal data and job queues", When Public Sector Workers Unionize, R. Freeman and C. Ichniowski, Chicago, University of Chicago Press.
Lee, S.-H. (2004), "A reexamination of public-sector wage differentials in the United States: evidence from the NLSY with geocode", Industrial Relations, vol. 43, No. 2, Berkeley, University of California.

Lucifora, C. and D. Meurs (2006), "The public sector pay gap in France, Great Britain and Italy", Review of Income and Wealth, vol. 52, No. 1, International Association for Research in Income and Wealth.

Machado, J. and J. Mata (2005), "Counterfactual decomposition of changes in wage distributions using quantile regression", Journal of Applied Econometrics, vol. 20, No. 4, John Wiley \& Sons.

Melly, B. (2005), "Public-private sector wage differentials in Germany: evidence from quantile regression", Empirical Economics, vol. 30, No. 2, Springer.

Mizala, A., P. Romaguera and S. Gallegos (2011), "Public-private wage gap in Latin America (1992-2007): a matching approach", Labour Economics, vol. 18, No. S1, Amsterdam, Elsevier.

OECD (Organization for Economic Cooperation and Development) (2011), Government at a Glance 2011, Paris.

Panizza, U. and C. Qiang (2005), "Public-private wage differential and gender gap in Latin America: spoiled bureaucrats and exploited women?", The Journal of Socio-Economics, vol. 34, No. 6, Amsterdam, Elsevier.

Postel-Vinay, F. and H. Turon (2007). "The public pay gap in Britain: small differences that (don't?) matter", The Economic Journal, vol. 117, No. 523, St. Andrews, Royal Economic Society.

Pratap, S.E. Quintin (2006), "Are labor markets segmented in developing countries? A semiparametric approach", European Economic Review, vol. 50, No. 7, Amsterdam, Elsevier.

Siminski, P. (2013), "Are low-skill public sector workers really overpaid? A quasi-differenced panel data analysis", Applied Economics, vol. 45, No. 14, Taylor \& Francis. 